\title{
Evaluation of women with postcoital bleeding by clinical examination, papsmear, colposcopy and histopathology of cervix
}

\author{
Srilakshmi Yarlagadda ${ }^{1 *}$, Rangarao Diddi ${ }^{2}$, Prasuna J. L. Narra ${ }^{1}$
}

\begin{abstract}
${ }^{1}$ Department of Obstetrics and Gynecology, ${ }^{2}$ Department of Pathology, Dr. Pinnamaneni Siddhartha Institute of Medical Sciences and Research Foundation, Krishna, Andhra Pradesh, India
\end{abstract}

Received: 02 May 2018

Accepted: 05 May 2018

\section{*Correspondence:}

Dr. Srilakshmi Yarlagadda,

E-mail: ysiri531@gmail.com

Copyright: (c) the author(s), publisher and licensee Medip Academy. This is an open-access article distributed under the terms of the Creative Commons Attribution Non-Commercial License, which permits unrestricted non-commercial use, distribution, and reproduction in any medium, provided the original work is properly cited.

\section{ABSTRACT}

Background: Postcoital bleeding refers to spotting or bleeding per vagina that occurs after intercourse and is not related to menstruation. Although there are multiple benign etiologies to this complaint, the most serious cause of postcoital bleeding is cervical cancer (3-5.5\%). Cervical cancer is the most common and preventable genital cancer of women. It has a long premalignant phase and with an ideal screening test with good sensitivity and specificity, we can diagnose and treat premalignant cervical lesions, preventing cervical cancer. The present study is aimed to evaluate the women with postcoital bleeding by clinical examination, pap smear, colposcopy and guided biopsy to detect premalignant cervical lesions and carcinoma cervix.

Methods: This was a prospective and retrospective study conducted from April, 2016 to March, 2018 for a period of 24 months in the Department of Obstetrics and Gynaecology on 100 women with postcoital bleeding at Dr. Pinnamaneni Siddhartha Institute of Medical Sciences and Research Foundation (Dr. PSIMS\&RF). After clinical examination, these women were subjected to pap smear, colposcopy and guided biopsy. The findings were correlated with histopathology of cervix. The sensitivity, specificity, positive predictive value, negative predictive value and accuracy of both papsmear and colposcopy were calculated.

Results: Sensitivity of papsmear was $71.42 \%$, specificity- $86.20 \%$, PPV-78.95\%, NPV-80.64\% and accuracy-80\%. Sensitivity of colposcopy was $90.47 \%$, specificity-89.65\%, PPV-86.36\%, NPV-92.85\% and accuracy-90\%.

Conclusions: These results establish colposcopy as an effective screening test for carcinoma cervix. Histopathology of suspected cervical lesion in colposcopy remains the gold standard for definitive diagnosis.

Keywords: Cervical cancer screening, Colposcopy, Postcoital bleeding, Papsmear, Premalignant lesions of cervix

\section{INTRODUCTION}

Post coital bleeding refers to spotting or bleeding per vagina that occurs after intercourse and is not related to menstruation. ${ }^{1}$ The prevalence of postcoital bleeding ranges from $0.7-9 \%$ of menstruating women. Spontaneous resolution has been documented in $51 \%$ of premenopausal women who are naturally menstruating after 2 years with no further signs of recurrence. ${ }^{2}$ About $30 \%$ of women with postcoital bleeding also experience abnormal uterine bleeding and $15 \%$ have dyspareunia.,
There are multiple etiologies among which most common are benign cervicitis, ectropion or cervical polyps. CIN or carcinoma can also cause post coital bleeding. ${ }^{5}$ The prevalence of cervical cancer in women with post coital bleeding is $3-5.5 \%$ and prevalence of CIN is $6.8-17.8 \% .^{6-}$ ${ }^{10}$ Cervical cancer is the second most common cancer in the women throughout the world.

Cervical cancer kills approximately 2,30,000 women annually and the vast majority of deaths occur in developing countries. Carcinoma cervix is the 5th most 
common cancer related cause of death among women in the developing world and it is the leading cause of cancer death in women in these countries. ${ }^{5}$ Most women with post coital bleeding have benign diseases like cervicitis, endometritis, cervical polyps, ectropion, vulvar atrophy, benign vascular neoplasms like AVH, hemangiomas and lymphangiomas and sexual abuse.

Table 1: Common causes of postcoital bleeding.

\begin{tabular}{|c|c|c|c|c|c|}
\hline $\begin{array}{l}\text { Benign } \\
\text { growths }\end{array}$ & Infection & $\begin{array}{l}\text { Genital/ } \\
\text { Vulvar lesions }\end{array}$ & Benign conditions & Malignancy & Trauma \\
\hline $\begin{array}{l}\text { Endometrial } \\
\text { polyps }\end{array}$ & Cervicitis & HSV lesions & Vaginal atrophy & Cervical cancer & Sexual abuse \\
\hline Cervical polyps & PID & Syphilis & Pelvic organ prolapse & Endometrial cancer & Foreign bodies \\
\hline \multirow[t]{3}{*}{$\begin{array}{l}\text { Cervical } \\
\text { ectropion }\end{array}$} & Endometritis & Chancroid & $\begin{array}{l}\text { Benign vascular } \\
\text { neoplasms }\end{array}$ & Vaginal cancer & \\
\hline & Vaginitis & LGV lesions & Endometriosis & & \\
\hline & & $\begin{array}{l}\text { Condyloma } \\
\text { accuminata }\end{array}$ & & & \\
\hline
\end{tabular}

Postcoital bleeding is the presenting complaint in $11 \%$ of women with cervical cancer. ${ }^{11}$ The most important risk factor for carcinoma cervix include women who have been infected with a high-risk strain of Human Papilloma Virus (HPV), the virus believed to cause cervical cancer. Other risk factors include immunosuppression and smoking.

Table 2: Risk of cervical cancer in women with postcoital bleeding.

\begin{tabular}{|ll|}
\hline Age (years) & Risk \\
\hline $20-24$ & $1: 44,000$ \\
\hline $25-34$ & $1: 5,600$ \\
\hline $35-44$ & $1: 2,800$ \\
\hline $45-54$ & $1: 2,400$ \\
\hline
\end{tabular}

The incidence of cervical cancer has been significantly decreased in the past decades due to enhanced screening for cervical cancer via cervical cytology either with or without testing for HPV and colposcopy to detect precancerous lesions of cervix. ${ }^{3}$ The long preclinical stage of cervical cancer during which precursor lesions can be treated conservatively and successfully make it an ideal target for screening.

The most common histopathological types of cervical cancer include Squamous cell carcinoma (69\%)and Adenocarcinoma (25\%). ${ }^{12}$ Of the two types, Adenocarcinoma may be less likely to present with postcoital bleeding as lesions may be higher in cervical canal and protected from the trauma of intercourse. ${ }^{13}$ Women with postcoital bleeding who are found to have cervical cancer often are diagnosed with a higher stage of cancer than asymptomatic women. ${ }^{14}$ VAIN also causes postcoital bleeding and unusual vaginal discharge. ${ }^{15}$ Vaginal cancer is another gynaecological malignancy which causes postcoital bleeding. Primary vaginal carcinoma is responsible for $3 \%$ malignant neoplasms of female genital tract. Primary vaginal carcinoma often be located on the posterior aspect of upper one-third of vagina which is in close proximity to cervix. It is believed that one of the most important risk factors for development of VAIN is from previous (or) concomitant cervical dysplasia. Post coital bleeding can be the presenting complaint in $90 \%$ of women with endometrial carcinoma. Primary malignant lymphoma and NonHodgkin's lymphoma of female genital tract can also be present with postcoital bleeding.

The objectives of this study are to screen women with postcoital bleeding for precancerous lesions and invasive carcinoma of cervix with papsmear, colposcopy and guided biopsy and to compare and correlate the findings of papsmear, colposcopy and histopathological examination of cervix.

\section{METHODS}

This prospective and retrospective study was done at Dr. PSIMS and RF, Chinoutapally, Andhra Pradesh, India, from April 2016-March 2018 for a period of two years on 100 women with postcoital bleeding who attended the Gynecology OPD. Patients details were noted regarding age, socioeconomic status, age at marriage, occupation of both patient and her husband, parity and usage of contraceptives. Detailed history was taken regarding postcoital bleeding, menstruation, dysmenorrhea, dyspareunia, intermenstrual bleeding, recurrent excessive white discharge per vagina associated with foul smell and itching, H/O DM. General and gynecological examination was done [examination of external genitalia, speculum and bimanual pelvic examination]

Papsmear denotes exfoliative cytology of cervix. It was taken from transformation zone. Endocervical smear was taken with cytobrush. If abnormal vaginal discharge was 
present, high vaginal swab for culture and sensitivity was sent. Papsmear was not taken during menses (or) vaginal douching, sexual intercourse, antibiotic taken in immediate past. The Bethesda classification system was used for cytological grading of pap smear. Because of low sensitivity [70-80\%] and high false negative results with papsmear, it was complemented with colposcopy to reduce the false negative cases.
Colposcopy is a simple, noninvasive optical method of visualisation of female lower genital tract under bright illumination and stereoscopic vision. It helps in locating the size and extent of suspicious areas over cervix and vagina by VIA, VILI and examination with green filter to study the vascular pattern. Abnormal colposcopic findings like acetowhite areas and unstained areas after lugol's iodine application were analyzed by Reid's Colposcopy Index.

Table 3: Reid's Colposcopy Index.

\begin{tabular}{|c|c|c|c|}
\hline $\begin{array}{l}\text { Colposcopic } \\
\text { signs }\end{array}$ & Zero point & One point & Two points \\
\hline Colour & $\begin{array}{l}\text { Low intensity acetowhitening Ning (not } \\
\text { completely opaque; indistinct acetowhitening } \\
\text { Ning, transparent or translucent acetowhitening } \\
\text { Ning. Acetowhitening Ning beyond the margin of } \\
\text { the transformation zone, pure snow-white colour } \\
\text { with intense surface shine (rare) }\end{array}$ & $\begin{array}{l}\text { Intermediate shade-gray/white } \\
\text { colour and shiny surface (most } \\
\text { lesions should be scored in this } \\
\text { category) }\end{array}$ & $\begin{array}{l}\text { Dull, opaque, oyster } \\
\text { white; gray }\end{array}$ \\
\hline $\begin{array}{l}\text { Lesion margin } \\
\text { and surface } \\
\text { configuration }\end{array}$ & $\begin{array}{l}\text { Microcondylomatous or micropapillary contoured } \\
\text { flat lesions with indistinct margins. } \\
\text { Feathered or finely scalloped margins. } \\
\text { Angular, jagged lesions, } 3 \\
\text { satellite lesions beyond the margin of } \\
\text { transformation zone }\end{array}$ & $\begin{array}{l}\text { Regular- shaped, symmetrical } \\
\text { lesions with smooth, straight } \\
\text { outlines }\end{array}$ & $\begin{array}{l}\text { Rolled, peeling edges. } \\
\text { Internal demarcation } \\
\text { between areas of } \\
\text { differing colposcopic } \\
\text { appearance. } \\
\text { A central area of high } \\
\text { grade change and } \\
\text { peripheral area of low } \\
\text { grade change }\end{array}$ \\
\hline Vessels & $\begin{array}{l}\text { Fine /uniform calibre vessels closely and } \\
\text { uniformly placed. Poorly formed patterns of fine } \\
\text { punctuation and/mosaic. } \\
\text { Vessels beyond the margin of transformation } \\
\text { zone. } \\
\text { Fine vessels within microcondylomatous or } \\
\text { micropapillary lesions }\end{array}$ & Absent vessels & $\begin{array}{l}\text { Well defined coarse } \\
\text { punctuation or coarse } \\
\text { mosaic }\end{array}$ \\
\hline Iodine staining & $\begin{array}{l}\text { Positive iodine uptake giving mahogany brown } \\
\text { colour, negative uptake of insignificant lesion, i.e. } \\
\text { yellow staining by lesion scoring } 3 \text { points or less } \\
\text { on the first three criteria. } \\
\text { Areas beyond the margins of transformation } \\
\text { zone, conspicuous on colposcopy, evident as } \\
\text { iodine negative areas (such areas are frequently } \\
\text { due to parakeratosis). }\end{array}$ & $\begin{array}{l}\text { Partial iodine uptake - } \\
\text { variegated, speckled } \\
\text { appearance. }\end{array}$ & $\begin{array}{l}\text { Negative iodine uptake } \\
\text { of significant lesion, i.e., } \\
\text { yellow staining by a } \\
\text { lesion already scoring } \\
\text { four points or more on } \\
\text { the first three criteria. }\end{array}$ \\
\hline
\end{tabular}

\section{Inclusion criteria}

- Sexually active women with postcoital bleeding.

\section{Exclusion criteria}

- Pregnant women.

- Women who underwent hysterectomy.

- Unmarried women.

- Diagnosed cases of carcinoma cervix.
Cervical biopsy was taken from abnormal areas on colposcopy. HPE of cervical biopsies was done by senior Pathologist at our institute.

Sensitivity, specificity, PPV, NPV and Accuracy of colposcopy in diagnosing lesions was calculated. Modified Reid's Index on colposcopy was validated with HPE of cervix. Hyteroscopy guided endometrial biopsy was done in women who also complain postmenopausal bleeding, menstrual abnormalities along with postcoital bleeding. 


\section{Statistical analysis}

Sensitivity $=\mathrm{TP} / \mathrm{TP}+\mathrm{FN}$, Specificity $=\mathrm{TN} / \mathrm{TN}+\mathrm{FP}$ $\mathrm{PPV}=\mathrm{TP} / \mathrm{TP}+\mathrm{FP}, \mathrm{NPV}=\mathrm{TN} / \mathrm{FN}+\mathrm{TN}$

Accuracy $=\mathrm{TP}+\mathrm{TN} / \mathrm{Total}$

The results were analyzed statistically by chi-square test and by calculating the p-value.

\section{RESULTS}

Age

In present study, majority of women were between 31-40 years (57\%). $23 \%$ were between $41-45$ years and $15 \%$ were above 45 years.

Table 4: Age.

\begin{tabular}{|l|l|}
\hline Age (years) & Number of cases \\
\hline $26-30$ & 5 \\
\hline $31-35$ & 26 \\
\hline $36-40$ & 31 \\
\hline $41-45$ & 23 \\
\hline$>45$ & 15 \\
\hline
\end{tabular}

\section{Pap smear results}

NILM was seen in maximum number of cases (62\%). On pap smear, LSIL was observed in 22\% and HSIL in 12\% cases. Carcinoma was detected in $4 \%$ women on pap smear.

\section{Correlation of age with pap smear}

In present study, most of younger women had NILM \& LSIL 93.54\% (29/31). On papsmear, HSIL and carcinoma were seen in women above 36 yrs $(20.25 \%)$.
Table 5: Pap smear results.

\begin{tabular}{|lll|}
\hline Pap smear & No. of cases & $\%$ \\
\hline NILM & 62 & 62 \\
\hline LSIL & 22 & 22 \\
\hline HSIL & 12 & 12 \\
\hline Carcinoma & 4 & 4 \\
\hline
\end{tabular}

NILM-Negative for Intraepithelial Lesion or Malignancy; LSIL-Low grade Squamous Intraepithelial Lesion; HSIL-High grade Squamous Intraepithelial Lesion

Table 6: Correlation of age with pap smear.

\begin{tabular}{|llllll|}
\hline Papsmear & $26-30$ & $31-35$ & $36-40$ & $41-45$ & $>45$ \\
\hline NILM & 4 & 19 & 20 & 12 & 7 \\
\hline LSIL & 1 & 5 & 7 & 5 & 4 \\
\hline HSIL & 0 & 2 & 3 & 4 & 3 \\
\hline Carcinoma & 0 & 0 & 1 & 2 & 1 \\
\hline
\end{tabular}

\section{Distribution of colposcopic lesions}

In present study, 56\% had benign inflammatory lesions in colposcopy. 24\% had low grade lesions and 14\% had high grade lesions. 6\% had invasive carcinoma in colposcopy.

\section{Table 7: Distribution of colposcopic lesions.}

\begin{tabular}{|lll|}
\hline Reid's Colposcopic score & No. of cases & $\%$ \\
\hline 0-2 (Benign inflammatory) & 56 & 56 \\
\hline 3-5 (low grade lesions) & 24 & 24 \\
\hline 6-8 (high grade lesions) & 14 & 14 \\
\hline$>8$ (invasive carcinoma) & 6 & 6 \\
\hline
\end{tabular}

\section{Correlation between pap smear and colposcopy}

Majority of women who had NILM on pap smear had benign inflammatory lesions in colposcopy (87.09\%) (54/62). 7 women had low grade lesions.

Table 8: Correlation between pap smear and colposcopy.

\begin{tabular}{|lllll} 
Pap smear & $\begin{array}{l}\text { Benign inflammatory } \\
\text { lesions in colposcopy (0-2) }\end{array}$ & $\begin{array}{l}\text { Low grade lesions in } \\
\text { colposcopy }\end{array}$ & $\begin{array}{l}\text { High grade lesions } \\
\text { in colposcopy (6-8) }\end{array}$ & $\begin{array}{l}\text { Invasive carcinoma } \\
\text { lesions in colposcopy (>8) }\end{array}$ \\
\hline NILM (62) & 54 & 7 & 1 & 0 \\
\hline LSIL (22) & 2 & 16 & 4 & 0 \\
\hline HSIL (12) & 0 & 1 & 9 & 2 \\
\hline $\begin{array}{l}\text { Carcinoma } \\
\text { (4) }\end{array}$ & 0 & 0 & 0 & 4 \\
\hline
\end{tabular}

Chi- square value- $105.146, \mathrm{p}$ value $<0.00001$ which is significant.

Only 1 out of 62 women who had NILM on pap smear had high grade lesion detected in colposcopy.

HSIL was observed on pap smear in 12 women.
Out of these, one woman had low grade lesion in colposcopy $(8.33 \%)$, 9 women $(75 \%)$ had high grade lesions and 2(16.6\%) had lesions suggestive of carcinoma. 
4 women whose pap smear showed carcinoma had invasive carcinoma lesions in colposcopy also.

\section{Histopathological analysis}

In present study, HPE of cervix showed chronic cervicitis with metaplasia in $58 \%$ cases. Mild dysplasia was observed in $17 \%$ cases and moderate-severe dysplasia was seen in $15 \%$ cases. $10 \%$ had invasive Squamous Cell Carcinoma in present study

\section{Correlation between pap smear and histopathology of cervix}

Out of 22 women who had LSIL on pap smear, 7 women had moderate-severe dysplasia of cervix in HPE $(31.81 \%)$.
5 women whose pap smear showed HSIL had Squamous Cell Carcinoma in HPE (41.66\%). Both papsmear and HPE of cervix turned out to be Squamous Cell Carcinoma in 4 cases.

Table 9: HPE analysis.

\begin{tabular}{|lcc|}
\hline HIPE Report & No. of cases & $\%$ \\
\hline $\begin{array}{l}\text { Chronic cervicitis with } \\
\text { metaplasia }\end{array}$ & 58 & 58 \\
\hline $\begin{array}{l}\text { Mild dysplasia } \\
\text { (LSIL) }\end{array}$ & 17 & 17 \\
\hline $\begin{array}{l}\text { Moderate-severe dysplasia } \\
\text { (HSIL) }\end{array}$ & 15 & 15 \\
$\begin{array}{l}\text { Squamous cell } \\
\text { carcinoma }\end{array}$ & 10 & 10 \\
\hline
\end{tabular}

Table 10: Correlation between papsmear and histopathology of cervix.

\begin{tabular}{|lllll|} 
Papsmear & $\begin{array}{l}\text { Chronic cervicitis with } \\
\text { metaplasia in HPE }\end{array}$ & $\begin{array}{l}\text { Mild dysplasia } \\
\text { in HPE }\end{array}$ & $\begin{array}{l}\text { Moderate to severe } \\
\text { dysplasia in HPE }\end{array}$ & $\begin{array}{l}\text { Squamous cell } \\
\text { carcinoma in HPE }\end{array}$ \\
\hline NILM (62) & 50 & 10 & 2 & 0 \\
\hline LSIL (22) & 8 & 6 & 7 & 1 \\
\hline HSIL (12) & 0 & 1 & 6 & 5 \\
\hline Carcinoma (4) & 0 & 0 & 0 & 4 \\
\hline
\end{tabular}

chi-square value- 69.157 , $p$ value $<0.00001$ which is significant.

\section{Sensitivity and specificity of pap smear}

Table 11: Sensitivity and specificity of pap smear.

\begin{tabular}{lll|}
\hline Papsmear & Positive HPE & Negative HPE \\
\hline Positive (38) & $30(\mathrm{TP})$ & $8(\mathrm{FP})$ \\
\hline Negative (62) & $12(\mathrm{FN})$ & $50(\mathrm{TN})$ \\
\hline $\begin{array}{l}\text { TP-True positive, } \\
\text { negative }\end{array}$ & FP-False positive, & FN-False negative,
\end{tabular}

In present study, the sensitivity of papsmear for detecting low grade lesions and above came out to be $71.42 \%$, specificity $86.20 \%$, PPV $78.95 \%$, and NPV $80.64 \%$ respectively. Accuracy of papsmear in present study was $80 \%$.

Table 12: Sensitivity and specificity of pap smear.

\begin{tabular}{|ll|}
\hline Papsmear & Percentage \\
\hline Sensitivity & 71.42 \\
\hline Specificity & 86.20 \\
\hline Positive predictive value & 78.95 \\
\hline $\begin{array}{l}\text { Negative } \\
\text { predictive value }\end{array}$ & 80.64 \\
\hline Accuracy & 80 \\
\hline
\end{tabular}

Table 13: Correlation between colposcopy and histopathology of cervix.

\begin{tabular}{|lllll|}
\hline $\begin{array}{l}\text { Colposcopy } \\
\text { Grade }\end{array}$ & $\begin{array}{l}\text { HPE-chronic } \\
\text { cervicitis with } \\
\text { metaplasia }\end{array}$ & $\begin{array}{l}\text { HIPE-Mild dysplasia } \\
\text { (LSIL) }\end{array}$ & $\begin{array}{l}\text { HIPE-Moderate-severe } \\
\text { dysplasia (HSIL) }\end{array}$ & $\begin{array}{l}\text { HIPE-carcinoma } \\
\text { Benign (56) }\end{array}$ \\
\hline Low grade lesion (24) & 6 & 3 & 1 & 0 \\
\hline High grade lesion (14) & 0 & 14 & 3 & 3 \\
\hline Invasive ca (6) & 0 & 0 & 11 & 6 \\
\hline
\end{tabular}

Chi- square value: 112.83 , p value $<0.00001$ which is significant. 


\section{Correlation between colposcopy and histopathology of cervix}

In present study, 56 women had benign inflammatory lesions in colposcopy. Out of them, $92.85 \%(52 / 56)$ had chronic cervicitis with metaplasia in HPE. 3 women had mild dysplasia $(5.38 \%)$ and one woman $(1.78 \%)$ had moderate-severe cervical dysplasia.14 women had high grade lesion in colposcopy. Out of them, $78.57 \%(11 / 14)$ had moderate-severe cervical dysplasia and $21.42 \%$ (3/14) had invasive Squamous Cell Carcinoma. All the women who had invasive carcinoma lesions in colposcopy had invasive Squamous Cell Carcinoma in histopathology also.

\section{Sensitivity and specificity of colposcopy}

In present study, the sensitivity of colposcopy for detecting low grade lesions and above came out to be $90.47 \%$, specificity $89.65 \%$, PPV $86.36 \%$, and NPV $92.85 \%$ respectively. Accuracy of colposcopy in present study was $90 \%$.

Table 14: Sensitivity and specificity of colposcopy.

\begin{tabular}{|lll|}
\hline Colposcopy & $\begin{array}{l}\text { Histopathology } \\
\text { Positive }\end{array}$ & $\begin{array}{l}\text { Histopathology } \\
\text { Negative }\end{array}$ \\
\hline Positive (44) & $38(\mathrm{TP})$ & $6(\mathrm{FP})$ \\
\hline Negative (56) & $4(\mathrm{FN})$ & $52(\mathrm{~TB})$ \\
\hline
\end{tabular}

Table 15: Sensitivity and specificity of colposcopy.

\begin{tabular}{|l|l|}
\hline Colposcopy & $\%$ \\
\hline Sensitivity & 90.47 \\
\hline Specificity & 89.65 \\
\hline Positive Predictive Value & 86.36 \\
\hline Negative Predictive Value & 92.85 \\
\hline Accuracy & 90 \\
\hline
\end{tabular}

\section{DISCUSSION}

Though postcoital bleeding has multiple benign etiologies, it is the presenting complaint in $11 \%$ of women with cervical cancer. Cervical cancer has a long pre-invasive period and appropriate intervention in this period always leads to decrease in the incidence of this dreadful disease.

Proper evaluation of women with postcoital bleeding is necessary to rule out cervical cancer. Conventional papsmear has its own limitations like inadequancy of smear, non-inclusion of endocervical cells, air drying of slide and fixation problems. Colposcopy is an excellent means of evaluating abnormal cervical cytology. Ultimately, HPE of cervix is necessary to establish the definitive diagnosis. In present study, we carefully evaluated women with postcoital bleeding by clinical features, papsmear, colposcopy and guided biopsy.
In present study, majority ( $57 \%$ ) of women were between 31-40 years. $23 \%$ were between $41-45 y$ rs and $15 \%$ were above 45 years. With increasing age, advanced lesions on pap test were observed.

In the study conducted by Shalini $\mathrm{R}$ et al the mean age of patients with invasive cancer was 41.3 years versus 32.9 years in patients with benign pathology, the difference being significant statistically. ${ }^{8}$ In the study by Himanshi $\mathrm{G}$ et al the mean age of patients with invasive cancer was 42.5 years versus 33.5 years in patients with benign pathology. ${ }^{16}$ On papsmear, NILM was seen in $62 \%$, LSIL in $22 \%$, HSIL in $12 \%$ and carcinoma in $4 \%$ women in present study. Himanshi $\mathrm{G}$ et al reported that $63 \%$ had inflammatory cytology, $15 \%$ had normal cytology, $6 \%$ had LSIL, 9\% had HSIL and 7\% had malignancy on papsmear in their study on women with postcoital bleeding. ${ }^{16}$ Manish Gupta et al reported in their study that $32 \%$ had inflammatory smear, $34.6 \%$ had LSIL and $18.7 \%$ had HSIL on papsmear in women with postcoital bleeding. ${ }^{17}$

In present study, $56 \%$ had benign inflammatory lesions in colposcopy. $24 \%$ had low grade lesions, $14 \%$ had high grade lesions and $6 \%$ had invasive carcinoma. With increasing age, advanced lesions in colposcopy were observed Manish Gupta et al reported that 34\% had Grade-I lesions, $8 \%$ had Grade-II and $17 \%$ had Grade-III lesions in colposcopy in their study. ${ }^{17}$ Himanshi $\mathrm{G}$ et al reported $30 \%$ of women with normal colposcopy findings, $46 \%$ with Grade-I ,7\% with Grade-II and 17\% with Grade-III lesions in their study. ${ }^{16}$

In present study, we compared the results obtained with pap smear and colposcopy. NILM was seen in 62 women. $87.09 \%$ who had NILM on papsmear had benign inflammatory lesions in colposcopy, $11.29 \%$ women had low grade lesions and 1 out of 62 women (1.61\%) who had NILM on pap smear had high grade lesion in colposcopy. LSIL was seen on papsmear in 22 women.

Out of them, $9.09 \%$ had benign inflammatory lesions in colposcopy, $72.72 \%$ women had low grade lesions and $18.18 \%$ had high grade lesions in colposcopy. HSIL was observed on pap smear in 12 women. Out of them, $8.33 \%$ had low grade lesions, $75 \%$ had high grade lesions in colposcopy and $16.6 \%$ had carcinoma. 4 women whose pap smear showed carcinoma had invasive Squamous Cell Carcinoma in colposcopy also.

Cervical histopathology showed chronic cervicitis with metaplasia in $58 \%$ cases. Mild dysplasia was seen in $17 \%$ cases, moderate-severe dysplasia in $15 \%$ cases. $10 \%$ had invasive Squamous Cell Carcinoma in present study.

Gupta $\mathrm{M}$ et al reported that mild dysplasia of cervix was seen in $14.6 \%$ and moderate-severe dysplasia was seen in $10.7 \%$ of women with postcoital bleeding in their study. ${ }^{17}$ Himanshi $\mathrm{G}$ et al reported that $29 \%$ of women with 
postcoital bleeding had chronic cervicitis and $8 \%$ had invasive cervical carcinoma in HPE in their study. ${ }^{16}$

Shalini $\mathrm{R}$ et al reported that $5.5 \%$ of women with postcoital bleeding had invasive cancer cervix in their study whereas Rosenthal AN et al reported $4 \%$ cases with invasive cancer cervix. ${ }^{8,9}$ Allen et al reported that $1 \%$ of women with postcoital bleeding had carcinoma cervix in their study and Ashrafgangoei $\mathrm{T}$ et al reported $1.8 \%$ cases with invasive cancer cervix in women with postcoital bleeding in their study. ${ }^{19,21}$ Authors compared the results of papsmear with HPE. In present study, 62 women had NILM on papsmear. Out of them $80.64 \%$ had chronic cervicitis with metaplasia in HPE, $16.12 \%$ had mild dysplasia and $3.22 \%$ had moderate- severe dysplasia. 22 women had LSIL on papsmear. Out of them, $36.36 \%$ had chronic cervicitis with metaplasia, $27.27 \%$ had low grade lesions, $31.82 \%$ had moderate- severe dysplasia and $4.54 \%$ had carcinoma. 12 women had HSIL on papsmear. Out of them, $8.33 \%$ had mild dysplasia, $50 \%$ had moderate- severe dysplasia, $41.67 \%$ had carcinoma in HPE. All the women who had lesions suggestive of carcinoma on papsmear had invasive Squamous Cell Carcinoma in histopathology also.

Sensitivity of papsmear was $71.42 \%$, specificity-86.20\%, PPV-78.95\%, NPV-80.64\% and accuracy-80\% in present study. Shalini R et al reported that papsmear had $56 \%$ sensitivity and $90 \%$ specificity in their study. ${ }^{8}$ Tehranian A et al reported that pap smear had $50 \%$ sensitivity and $86.5 \%$ specificity in their study on women with postcoital bleeding. ${ }^{3}$

We compared the results of colposcopy with HPE. In present study, 56 women had benign inflammatory lesions in colposcopy. Out of them $92.85 \%$ had chronic cervicitis with metaplasia, $5.36 \%$ had mild dysplasia and only 1 woman $(1.78 \%)$ had moderate-severe dysplasia. 24 women had low grade lesions in colposcopy. Out of them, $25 \%$ had chronic cervicitis with metaplasia, $58.33 \%$ had mild dysplasia, $12.5 \%$ had moderate-severe dysplasia and $4.17 \%$ had carcinoma.

14 women had high grade lesions in colposcopy. Out of them $78.57 \%$ had moderate-severe cervical dysplasia and $21.42 \%$ had invasive squamous cell carcinoma. All the women who had lesions suggestive of carcinoma in colposcopy had invasive squamous cell carcinoma in histopathology also.

Sensitivity of colposcopy was $90.47 \%$, specificity$89.65 \%$, PPV-86.36\%, NPV-92.85\% and accuracy-90\% in present study. Tehranian A et al reported that colposcopy had $79 \%$ sensitivity in their study on evaluation of women with postcoital bleeding. ${ }^{3}$

Present findings in this study show that colposcopy is more sensitive, specific and accurate than pap smear in detecting premalignant lesions of cervix and cervical carcinoma in women with postcoital bleeding. However, it should be confirmed with histopathology of cervical lesions for definitive diagnosis.

\section{CONCLUSION}

It is advisable to perform both papsmear and colposcopy in women with postcoital bleeding to detect premalignant cervical lesions and invasive carcinoma cervix. However, histopathology of suspected lesion in colposcopy remains the gold standard for definitive diagnosis in view of false positives and false negatives with papsmear and colposcopy.

\section{ACKNOWLEDGMENTS}

Authors would like to thank Dr. Sajana Gogineni, Professor and HOD of the Department of Obstetrics and Gynecology at our institute for her guidance and support in conducting the study. We would like to thank Dr. Manogna and Dr. Sindhu, Postgraduates in the Department of Obstetrics and Gynecology at our institute for their help in conducting the study. We would like to thank Mrs. Savitri, statistician, for analysing the data. We would like to thank all the patients and their attendants for their cooperation and contribution.

Funding: No funding sources

Conflict of interest: None declared

Ethical approval: The study was approved by the Institutional Ethics Committee

\section{REFERENCES}

1. Tarney CM, Han J. Postcoital bleeding: a review on etiology, diagnosis, and management. Obstet Gynecol Int. 2014;2014.

2. Shapley M, Blagojevic-Bucknall M, Jordan KP, Croft PR. The epidemiology of self-reported intermenstrual and postcoital bleeding in the perimenopausal years. BJOG: Int J Obstet and Gynaecol. 2013;120:1348-55.

3. Tehranian A, Rezaii N, Mohit M, Eslami B, Arab M, Asgari Z. Evaluation of women presenting with postcoital bleeding by cytology and colposcopy. Int $\mathrm{J}$ Gynecol and Obstet. 2009;105:18-20.

4. Selo-Ojeme DO, Dayoub N, Patel A, Metha M. A clinico-pathological study of postcoital bleeding. Arc Gynecol Obstet. 2004;270:34-6.

5. Fraser IS, Petrucco OM. Management of intermenstrual and postcoital bleeding, and an appreciation of the issues arising out of the recent case of O'Shea versus Sullivan and Macquarie pathology. Aus NZ J Obstetrics Gynaecol. 1996;36:67-73.

6. Pardanani NS, Tischler LP, Brown WH, Feo ED. Carcinoma of cervix. Evaluation of treatment in community hospital. New York state J Medi. 1975;75:1018. 
7. Pretorius R, Semrad N, Watring W, Fotheringham N, Presentation of cervical cancer, Gynecol Oncol. 1991;42:48-53.

8. Shalini R, Amita S, Neera MA. How alarming is post-coital bleeding-a cytologic, colposcopic and histopathologic evaluation. Gynecol Obstet Investi. 1998;45:205-8..

9. Rosenthal AN, Panoskaltsis T, Smith T, Soutter WP. The frequency of significant pathology in women attending a general gynaecological service for postcoital bleeding. BJOG: Int J Obstet Gynaecol. 2001;108:103-6.

10. Jha S, Sabharwal S. Outcome of colposcopy in women presenting with postcoital bleeding and negative or no cytology-results of a 1-year audit. J Obstet Gynaecol. 2002;22:299-301.

11. Anorlu RI, Abdul-Kareem FB, Abudu OO, Oyekan TO. Cervical cytology in an urban population in Lagos, Nigeria. J Obstet Gynaecol. 2003;23:285-8.

12. Kurman RJ. Tumors of the cervix, vagina, and vulva. Atlas Tumor Pathol. 1992;4:55-61.

13. Viikki M, Pukkala E, Hakama M. Bleeding symptoms and subsequent risk of gynecological and other cancers. Acta Obstet Gynecol Scandina. 1998;77:564-9.

14. deSouza NM, Gilderdale DJ, Soutter WP, McIndoe GA, Krausz T. Stage I cervical cancer: tumor volume by magnetic resonance imaging of screen-detected versus symptomatic lesions. J Nat Cancer Insti. 1997;89:1314-5.

15. Zeligs KP, Byrd K, Tarney CM, Howard RS, Sims BD, Hamilton CA, Stany MP. A clinicopathologic study of vaginal intraepithelial neoplasia. Obstet and Gynecol. 2013;122:1223-30.

16. Gangwal H, Rajoria L. Evaluation of Postcoital Bleeding by Clinical And Pathological Finding. IOSR J Dent Med Sci. 2015;14:31-4.

17. Gupta M, Sharma A, Agarwal N, Agarwal A. Clinical profile of women with postcoital bleeding. Univer J Health Sci. 2016;2:106-8.

18. Shapley M, Jordan J. A systematic review of postcoital bleeding and risk of cervical cancer. Br J Gen Pract. 2006;56:453-60.

19. Abdelkrim M, Abedelnacer T, Abdelkrim S. Frequency Of Significant Cervical Pathology In Women Attending A Teaching Gynaecological Service For Postcoital Bleeding With Normal Cytology. Int J Gynecol Canc 2016;26:28-9.

Cite this article as: Yarlagadda S, Diddi R, Narra PJL. Evaluation of women with postcoital bleeding by clinical examination, papsmear, colposcopy and histopathology of cervix. Int J Reprod Contracept Obstet Gynecol 2018;7:2184-91. 